\title{
Transmission of Social-Cultural Values Through Education in the Yogyakarta Community Tradition
}

\author{
Sadam Fajar Shodiq ${ }^{1, *}$ Abd. Madjid ${ }^{2}$ \\ ${ }^{1}$ Universitas Muhammadiyah Yogyakarta \\ ${ }^{2}$ Universitas Muhammadiyah Yogyakarta \\ *Email: sadamfajarshodiq@fai.umy.ac.id
}

\begin{abstract}
Transmission of socio-cultural values is seen as a kind of "black box." A student usually obtains their socio-cultural values from their role models (probably their parents or other adults), but how this socialization process works is not explicitly spelled out. Information on socio-cultural values is regarded as a fact that applies to everyone in all circumstances. One consequence is that information on socio-cultural values can then be disseminated further, spreading through social networks on the broader community and population. Different experimental paradigms can simulate the spread of information on socio-cultural values through social networks with different structural properties. This study aims to analyze the socio-cultural values in the traditions of the Yogyakarta people transmitted through education. This study's approach is qualitative, with research subjects of the principal, teachers, and students. Data collection techniques were through observation, interviews, and documentation. The analysis includes data reduction, data display, and conclusion drawing/verification. The results showed that (1) transmission of socio-cultural values is not carried out by design; (2) socio-cultural values transmitted to students such as cooperation values, politeness, and discipline; and (3) the process of transmitting socio-cultural values carried out in the classroom learning activities and extracurricular activities.
\end{abstract}

Keywords: Transmission, Values, Socio-Culture, Education, Tradition

\section{INTRODUCTION}

Social values are an important part of people's culture [1]. Those values explain the steadiness of the social order. they supply general tips for social behavior. Values such as basic rights, patriotism, respect for human dignity, rationality, sacrifice, individuality, equality, democracy, etc. guide our behavior in some ways. price may be a criterion by which individuals choose their lifestyle, set their priorities, and choose from various actions.

Value could be a commonplace of social behavior that comes from social interactions and is accepted as a constituent truth of the structure. they're objects desired by social conditions. These are goals that are culturally defined and involve "sentiment and significance." It consists of "aspirational references" [2]. Values are expected to be followed to assess and appraise social interactions, goals, means, ideas, feelings, and expected behaviors. while not such analysis standards, it'll be tough to guage individual behavior or social actions. Values aim to integrate expected individual behavior and social policy. It tends to forestall tension and therefore contains a tension management role.

Value is "an explicit concept of implicit, distinct from a personal or a bunch of fascinating traits that influence the selection of accessible modes and therefore the outcome of associate action." In fact, worth is associate abstract term that's typically considered an economic conception [3]. In the words of John Dewey, "Value means above all, to value, to value, to value, to estimate. It means the act of appreciating something which clarifies it and also the act of judging its nature and sums its value in comparison to something else" [4].

Value is associate integral a part of philosophy. Therefore, instructional goals are naturally regarding values. All education is, in fact, terribly value-oriented. each instructional goal, whether or not originating from an individual, family, community, school, or the education system, is believed to be smart. "Good" is meant here, "bad avoidance." If it may be objective, it's not smart. Then there's no reason to pursue. But again, identical question arises, and when the question "what is 
value?" It appears that we know something about religion, philosophy, and beliefs.

Social goals and guiding beliefs are thought of to be essential aspects of a culture, then, various aspects of culture are also 'valued' by society; and the ideas that are behind which they consider valuable are referred to as values [5]. Value is that the most popular preference and conception. in line with Kluckohn, value is a conception of what is desired and not something that is "simply desired." Value is defined as something that is desired and worthy of respect for their own benefit. Human values are outlined as values that facilitate humans to measure harmonical with the planet.

The values that will be enclosed within the general definition of human values are love, brotherhood, respect for others, together with plants and animals, honesty, sincerity, non-violence, gratitude, tolerance, sense of responsibility, cooperation, and independence. Therefore, the use of the word "value" here stands for the idea used by men. within the most elementary sense, price suggests that no matter i actually value, want, or relish by anyone at any time. this is often the particular expertise of enjoying the specified object or activity. Hence, price is that the realization of existing desires [6]. Although worth has been same to be associate degree expertise of delight and joy, the expertise of import isn't below the direct management of reason.

Everyone has their own beliefs, values, and culture. But to be honest, do we all respect other cultures and values? It's important to think that you never challenge other people's values and become discouraged when it comes to proving you right and others wrong. Individual values and beliefs create cultural relativism that blinds and limits what they can accept. Cultural relativism leads to a tendency towards exclusion, which is the fastest route to prejudice. In this century, diversity has become a vital point in the community. Because we are in the process of learning and teaching new values and cultures, cultural reproduction will continue from generation to generation.

To answer the question of the mechanism of cultural transmission, a qualitative approach is suitable. though investigations into cultural dynamics began quite 0.5 a century agone, it had a protracted dormancy solely to search out its revivification within the last decade [7][9].

To extend the analysis tradition, we tend to investigate the micro- and macro-level institutional-level psychological feature mechanisms of implicit perspective transmission. perspective is a definite or implicit tendency to suppose, feel, or behave in sensible or dangerous ways in which towards an object or category of objects; wide command attitudes have continuously been thought-about a very important facet of culture [10]. Implicit attitudes - introspectively unknown (or inaccurately identified) traces of past experiences that mediate favorable or unfavorable feelings, thoughts, or actions towards a social object raise terribly attention-grabbing questions on the culture of contagion. though they're widespread during a population, therefore forming a part of the culture (e.g., implicit gender-based attitudes toward arithmetic and science; implicit prejudice against minorities), they will not be directly evident or (need to) be spoken verbally. people during a society, thus, cannot derive their implicit attitudes solely by perceptive the implicit attitudes of others or by specific communication. Then, how is the implicit "value" transmitted?

The articles emphasize the essential role of education and culture in our perfection as people. Progress is that the results of meeting with others. beneath the domes of globalisation and migration, the issues of education are more and more numerous. during this new world, it is important to accept other people's experiences. this text is a trial to clarify a number of the causes of the difficulties sweet-faced by education and determine barriers to the transmission of socio-cultural values to tradition-based academic establishments in society. In terms of social dynamics, education plays an essential mandate to retort befittingly to the correct to distinction, to equality, to produce effective solutions that promote diversity in colleges. fashionable society emphasizes the role and purpose of colleges in an exceedingly pluralist world, supported diversity. In such a world, who must change: college or students? this text emphasizes the concept that we tend to must respect the variations between students, and education should be accessible to any or all individuals in spite of their cultural, ethnic, religious, and social development.

It is additionally emphasised that valence includes diversity in education between cultures or philosophical system interactions. each philosophical system education mechanisms and intercultural education are targeted on understanding cultural things in fashionable society, higher communication with individuals from alternative cultures, attitudes tailored to cultural diversity, open minds to social interactions [11]. Throughout this article, there are references to the role of education, the role of culture, and social interactions in inventive individual relationships aimed toward equality. this means equality, values diversity, social justice, and therefore the same distribution of power among totally different ethnic teams.

\section{RESEARCH METHOD}

This research was conducted using qualitative research techniques [12]-[15] to explore the possible relationship between cultural identity (community traditions) and education for the process of transmitting socio-cultural values in Yogyakarta. Focus group discussions were the main data source. We compiled focus groups from each school with pre-prepared 
questions in order to find evidence of a possible correlation between cultural identity (tradition) and education in general with respect to all curriculum areas.

The focus groups included students from different backgrounds: schools with public and private backgrounds in the vicinity of the palace and in the suburbs. Discussions were conducted by selecting study participants where they were asked several questions to find out what they think about their cultural identity (tradition) and its relation to their learning in general.

This study had been established in 3 public and private elementary schools of SD Muhammadiyah Suronatan, SD Negeri 2 Keputran, and SD Muhammadiyah Sapen. The input of students from the three schools was very diverse with different traditional backgrounds. The development of student learning was analyzed in this study by exploring the differences in their cultural identities and the influence of cultural characteristics on learning and how the process of transmitting socio-cultural values from each school.

Apart from interviews and discussions with research subjects, data collection was also carried out by direct observation in various educational activities, both in learning and extracurricular activities and other activities. Data collection was also supported through the results of documentation obtained either directly or documents that were already available in each school.

In conducting data analysis, there were several stages. The first stage was by reducing data that has been collected, then we select and map, primary and secondary data, apart from unused data. From the mapped and selected data it was displayed and followed by verification or drawing conclusions on the reduced and displayed data. To maintain the validity of the data and not cause bias, we triangulated the data, either by extending the observation time or conducting interviews with other respondents.

\section{FINDING AND DISCUSSION}

\subsection{Socio-Cultural Values of Yogyakarta Instilled to Students in Schools}

Based on observations, interviews and documentation, the results of this study are as follow:

Table 1. Research Result

\begin{tabular}{|c|c|c|c|}
\hline $\begin{array}{l}\text { Schools Value } \\
\text { Transmission }\end{array}$ & $\begin{array}{c}\text { SD Muhammadiyah } \\
\text { Suronatan }\end{array}$ & SD Negeri 2 Keputran & SD Muhammadiyah Sapen \\
\hline $\begin{array}{l}\text { Students } \\
\text { characteristics }\end{array}$ & $\begin{array}{l}\text { Students at SD } \\
\text { Muhammadiyah Suronatan are } \\
\text { from various regions within the } \\
\text { city of Yogyakarta and outside } \\
\text { the city, such as Kasihan and } \\
\text { Sleman. This school has an } \\
\text { achievement where it is always } \\
\text { ranked } 1 \text { or } 2 \text { when the UN. } \\
\text { SD Muhammadiyah Suronatan } \\
\text { also has adequate facilities, so } \\
\text { it can be concluded that most of } \\
\text { its students come from the } \\
\text { middle class. The school } \\
\text { environment is quite conducive } \\
\text { because there are no passing } \\
\text { vehicles so it can help to focus. }\end{array}$ & $\begin{array}{l}\text { SD N } 2 \text { Keputran has a } \\
\text { variety of students, not only } \\
\text { Muslims but also some non- } \\
\text { Muslims. This elementary } \\
\text { school also has students with } \\
\text { various socio-economic } \\
\text { levels, with a total of } 456 \\
\text { students. The facilities at this } \\
\text { school are standard. }\end{array}$ & $\begin{array}{l}\text { SD Muhammadiyah Sapen } \\
\text { has students from various } \\
\text { regions in Jogja because this } \\
\text { school is quite a favorite } \\
\text { among middle-high school } \\
\text { students. Meanwhile, } \\
\text { according to Pak Agung as } \\
\text { the principal, parents of } \\
\text { students at SD } \\
\text { Muhammadiyah Sapen are } \\
\text { mostly people who have } \\
\text { higher education. The } \\
\text { school's facilities are } \\
\text { adequate, and during break } \\
\text { time, the homeroom teacher } \\
\text { will still be in class to eat } \\
\text { together with his students, } \\
\text { and also teach students to } \\
\text { have good eating habits } \\
\text { directly. }\end{array}$ \\
\hline $\begin{array}{l}\text { Local } \\
\text { Traditions }\end{array}$ & $\begin{array}{l}\text { The tradition adopted at SD } \\
\text { Muhammadiyah Suronatan is } \\
\text { Javanese custom. Children } \\
\text { understand Javanese traditions } \\
\text { well, but this school is only } \\
\text { limited to introducing not } \\
\text { teaching all Javanese traditions } \\
\text { to its students. According to }\end{array}$ & $\begin{array}{l}\text { The tradition at SD } \mathrm{N} 2 \\
\text { Keputran adheres to a thick } \\
\text { Javanese tradition due to its } \\
\text { proximity to the palace. In } \\
\text { this elementary school, all } \\
\text { traditional Javanese } \\
\text { activities are introduced and } \\
\text { taught with no exception. SD }\end{array}$ & $\begin{array}{l}\text { SD Muhammadiyah Sapen } \\
\text { adheres to the Javanese } \\
\text { tradition. The children at SD } \\
\text { Muhammadiyah Sapen } \\
\text { understand Javanese tradition } \\
\text { through social activities that } \\
\text { are often carried out at this } \\
\text { school, for example, social }\end{array}$ \\
\hline
\end{tabular}


Table 1. Research Result

\begin{tabular}{|c|c|c|c|}
\hline $\begin{array}{l}\text { Schools Value } \\
\text { Transmission }\end{array}$ & $\begin{array}{c}\text { SD Muhammadiyah } \\
\text { Suronatan }\end{array}$ & SD Negeri 2 Keputran & SD Muhammadiyah Sapen \\
\hline & $\begin{array}{l}\text { Mister Budi, as the principal of } \\
\text { the school, not all Javanese } \\
\text { customs are in accordance with } \\
\text { Islamic aqidah. For example, } \\
\text { the Sekaten celebration was } \\
\text { introduced but discouraged. } \\
\text { However, for other activities, } \\
\text { such as gamelan, language, and } \\
\text { the value of mutual cooperation } \\
\text { are taught in this school. }\end{array}$ & $\begin{array}{l}\text { N } 2 \text { Keputran prioritizes the } \\
\text { value of art, where the } \\
\text { extracurricular dance } \\
\text { members are almost all } \\
\text { students. } \\
\text { At the end of each semester, } \\
\text { during changing grades, the } \\
\text { school holds an art } \\
\text { performance where each } \\
\text { class shows their dance. This } \\
\text { elementary school also } \\
\text { implements greeting } \\
\text { activities in the morning } \\
\text { with the teacher to introduce } \\
\text { humility to students. }\end{array}$ & $\begin{array}{l}\text { service, distribution of zakat } \\
\text { fitrah, and cultural festivals } \\
\text { that are routinely held. In } \\
\text { addition, Muhammadiyah } \\
\text { Sapen Elementary School } \\
\text { also provides not only } \\
\text { homework related to subjects, } \\
\text { but also social values. For } \\
\text { example, finding out the } \\
\text { name of the RT in the } \\
\text { neighborhood. In addition, } \\
\text { there is nembang macapat } \\
\text { intracurricular, where } \\
\text { students will learn Javanese } \\
\text { cultural philosophy. }\end{array}$ \\
\hline $\begin{array}{l}\text { The } \\
\text { Inculcation } \\
\text { Approach }\end{array}$ & $\begin{array}{l}\text { SD Muhammadiyah Suronatan } \\
\text { uses an Inculcation Approach, } \\
\text { where they emphasize the } \\
\text { inculcation of social values to } \\
\text { students with values that come } \\
\text { from society and culture. In this } \\
\text { approach, education is also } \\
\text { tasked with instilling values so } \\
\text { that students must position } \\
\text { themselves efficiently } \\
\text { according to the roles } \\
\text { determined by society. In } \\
\text { addition, this value approach } \\
\text { also has the goal of accepting } \\
\text { social values to students and } \\
\text { replacing undesirable values in } \\
\text { students. For example, For } \\
\text { example, these students visit } \\
\text { the neighbors before } \\
\text { Ramadhan, do Takziah, and } \\
\text { social service. It shows that } \\
\text { students understand how to } \\
\text { behave, courtesy, and mutual } \\
\text { cooperation between } \\
\text { communities. Students are also } \\
\text { taught to do habituation, such } \\
\text { as shaking hands with the } \\
\text { teacher in the morning, using } \\
\text { Javanese krama with older } \\
\text { people. }\end{array}$ & $\begin{array}{l}\text { SD N } 2 \text { Keputran uses the } \\
\text { Values Clarification } \\
\text { Approach and also the } \\
\text { Inculcation Approach, } \\
\text { where SD N } 2 \text { Keputran } \\
\text { helps students to realize their } \\
\text { feelings and actions by } \\
\text { thinking rationally and also } \\
\text { using emotional awareness. } \\
\text { This is done through the } \\
\text { activity of performing arts / } \\
\text { cultural titles, which is } \\
\text { carried out annually, where } \\
\text { students will learn to work } \\
\text { together to use their rational } \\
\text { thinking and emotional } \\
\text { awareness. In this } \\
\text { clarification, the approach is } \\
\text { too complex, so there are } \\
\text { methods, one of which is } \\
\text { helping students to can } \\
\text { communicate openly so that } \\
\text { students can reflect on social } \\
\text { thoughts, feelings, and } \\
\text { actions through performing } \\
\text { arts. In addition to this } \\
\text { approach, SD N } 2 \text { Keputran } \\
\text { also uses the Inculcation } \\
\text { Approach because it } \\
\text { provides social cultivation to } \\
\text { students with values from } \\
\text { society and culture, such as } \\
\text { shaking hands in the } \\
\text { morning and using Javanese } \\
\text { in everyday life. Also, dance } \\
\text { is a part of the culture. }\end{array}$ & $\begin{array}{l}\text { SD Muhammadiyah Sapen } \\
\text { uses the Inculcation } \\
\text { Approach method, where the } \\
\text { value implanted is tepo sliro } \\
\text { or tolerance between people } \\
\text { coming from the culture or } \\
\text { values of Yogyakarta. The } \\
\text { activities carried out at } \\
\text { Muhammadiyah Sapen } \\
\text { Elementary School use an } \\
\text { action learning approach } \\
\text { where the activities mostly } \\
\text { involve students in social } \\
\text { activities either individually } \\
\text { or collectively, such as social } \\
\text { services, distribution of zakat } \\
\text { fitrah, distribution of basic } \\
\text { necessities for } \\
\text { underprivileged residents, } \\
\text { and also learning nembang } \\
\text { macapat where there are } \\
\text { many Javanese philosophies } \\
\text { in it. }\end{array}$ \\
\hline $\begin{array}{l}\text { Instilled } \\
\text { Values }\end{array}$ & $\begin{array}{l}\text { The values instilled in SD } \\
\text { Muhammadiyah Suronatan are } \\
\text { Yogyakarta's customs and } \\
\text { traditions. The spirit of the } \\
\text { Yogyakarta, }\end{array}$ & $\begin{array}{l}\text { The values instilled in SD N } \\
2 \text { Keputran are the adiguna } \\
\text { adiluhung, the dance culture, } \\
\text { and politeness. }\end{array}$ & $\begin{array}{l}\text { The values instilled in SD } \\
\text { Muhammadiyah Sapen are } \\
\text { mostly tepo sliro through } \\
\text { activities to make students } \\
\text { have a tepo sliro attitude. }\end{array}$ \\
\hline
\end{tabular}


Table 1. Research Result

\begin{tabular}{|c|c|c|c|}
\hline $\begin{array}{l}\text { Schools Value } \\
\text { Transmission }\end{array}$ & $\begin{array}{c}\text { SD Muhammadiyah } \\
\text { Suronatan }\end{array}$ & SD Negeri 2 Keputran & SD Muhammadiyah Sapen \\
\hline & $\begin{array}{l}\text { cooperation, was also taught. } \\
\text { However, traditional values } \\
\text { that are not in accordance with } \\
\text { Islamic religion are not taught. }\end{array}$ & & $\begin{array}{l}\text { Also, manners, courtesy, and } \\
\text { politeness are encouraged. }\end{array}$ \\
\hline $\begin{array}{l}\text { Inculcation } \\
\text { Methods }\end{array}$ & $\begin{array}{l}\text { The method of instilling values } \\
\text { is by habituation, where the } \\
\text { children are accustomed to } \\
\text { shaking hands with the teacher } \\
\text { when leaving for school, then } \\
\text { for grade } 4,5,6 \text { doing Dhuha } \\
\text { prayer. Students are } \\
\text { accustomed to using Javanese } \\
\text { manners for older people, and } \\
\text { activities outside of lessons that } \\
\text { are often carried out to get } \\
\text { students used to working } \\
\text { together with other students, } \\
\text { such as takziah activities if } \\
\text { somebody passes away, doing } \\
\text { social services, and joining } \\
\text { outdoor activities called Live } \\
\text { In which are held between } \\
\text { semesters. }\end{array}$ & $\begin{array}{l}\text { The method of inculcation at } \\
\text { SD N } 2 \text { Keputran is through } \\
\text { habituation, where children } \\
\text { are required to shake hands } \\
\text { in the morning as a form of } \\
\text { introduction to manners, and } \\
\text { conditioning for performing } \\
\text { arts activities, } \\
\text { extracurricular activities, } \\
\text { and other activities so that } \\
\text { activities become conducive. }\end{array}$ & $\begin{array}{l}\text { The method of value } \\
\text { cultivation carried ou at } \\
\text { Muhammadiyah Sapen } \\
\text { Elementary School is to use } \\
\text { the filling method where their } \\
\text { activities are related to the } \\
\text { value of tepo sliro, for } \\
\text { example, the distribution of } \\
\text { basic necessities to } \\
\text { underprivileged people, zakat } \\
\text { fitrah, and social service. In } \\
\text { addition, there is also } \\
\text { intracurricular activities of } \\
\text { mocopat song. Meanwhile, } \\
\text { there is an example where the } \\
\text { class teachers accompany } \\
\text { their students to eat together } \\
\text { and give direct examples of } \\
\text { how to eat well, and other } \\
\text { social values such as sharing } \\
\text { food, etc. }\end{array}$ \\
\hline Goals & $\begin{array}{l}\text { There is communication that } \\
\text { exists between schools, } \\
\text { parents, and the community in } \\
\text { an effort to cultivate character. }\end{array}$ & $\begin{array}{l}\text { Integrated subjects, } \\
\text { community meetings, and } \\
\text { extra activities held at the } \\
\text { school. }\end{array}$ & $\begin{array}{l}\text { There is a commitment from } \\
\text { the parents in accompanying } \\
\text { their children. They have a } \\
\text { high level of awareness that } \\
\text { children must be taught the } \\
\text { values of the fading Javanese } \\
\text { culture. }\end{array}$ \\
\hline Challenges & $\begin{array}{l}\text { Monitoring the internalization } \\
\text { of values outside of school. }\end{array}$ & $\begin{array}{l}\text { Some parents are less } \\
\text { responsive to the school. } \\
\text { Parents' responses vary. } \\
\text { There are parents who are } \\
\text { responsive, adequate, } \\
\text { ordinary, and apriori } \\
\text { because they are busy in } \\
\text { their work, so they don't } \\
\text { have much free time. When } \\
\text { the school does not receive } \\
\text { a positive response, this can } \\
\text { be an obstacle in optimizing } \\
\text { students to have the desired } \\
\text { socio-cultural values. }\end{array}$ & $\begin{array}{l}\text { Upholding the commitment } \\
\text { of teachers, parents, and the } \\
\text { community in maintaining } \\
\text { and monitoring the values } \\
\text { that have been instilled in } \\
\text { students }\end{array}$ \\
\hline
\end{tabular}

\subsection{Cultural Assets, Social Assets, and Cultural Values}

The cultural asset is a collection of characteristics, features and 'tastes' that are prized in a particular society [16] and reproduces an elite status through objects and information that represents cultural goods. Bourdieu
(1986) divides the idea of cultural asset into three distinct elements; expresses the impression that the asset is acquired passively from time to time, for example as a result of family upbringing; aims related to acquisition but also awareness of the object either for benefit or success. [16], for example, is the knowledge and ability to buy expensive paintings; and, institutionalization, in 
which some form of institutional recognition is given for achievement, often closely linked to educational success. Hence, Bourdieu's acquisition of these key aspects gives the individual the power to act and join certain fields.

Cultural assets are distributed and replicated by social assets. Social benefit refers to the mutual 'value' generated by social networks and civil society to society. [5]. Like cultural values, the social asset itself is intangible, but it can be understood in the different ways in which it is produced. For Bourdieu, the social asset is a value built into social networks that can be realized by individuals for their benefit [16]. The social asset is the number of resources, real or virtual, acquired by a person or a community on the basis of a long-term network of more or less institutionalized relationships of shared understanding and recognition. Putnam (2000), meanwhile, is worried that social assets are diminishing due to evolving habits of accommodation, work and leisure. Social and cultural assets will help to create the universal ideals that we are now looking for.

Cultural worth as an idea is understood intuitively however, at identical time, by trial and error tough to tie. One use of this term for cultural organizations is to borrow economic vocabulary to justify disbursal on culture, and real problems are close the way to worth nonmarket product and therefore the value carries individuals. This is related to the uncomfortable relationship between 'intrinsic' and 'instrumental' cultural values. Who defines and determines cultural values also, to some extent, defines what 'values' are. Therefore, each are typically supported by political, economic, and social factors for the community [5].

Cultural values, such as cultural properties, are commonly viewed as hegemonic regimes. [18]. It is about what civilization values in 'high' cultural heritage and is, therefore, how of making price hierarchies that replicate and reproduce social hierarchies prevailing in society or, additional broadly speaking, civilization. The value of a cultural item can be judged by people's readiness to pay for it. Here we tend to aim to suppose the ways that during which cultural values are essential to people and communities and are embedded in everyday cultural practices. we tend to frame cultural values as variations in however people and communities do activities to precise things that are valuable to them.

They position social media and digital space as a 'technique' that externalizes information in such a way that it can be distributed through space and time. [3]. In this context, writing letters, drawing, tweeting, or sharing images via Instagram are all techniques that connect our current knowledge and actions to the knowledge and actions that could take place in the future and open up the possibility of individual, collective action.

That is, there are implications on however and why data is transmitted. As such, the shift from bequest analog technology keep in place-based archives to web-based digital networks impacts however this knowledge is generated, reinterpreted in digital kind, understood, and tailored by people and communities. This, in turn, changes a number of the socio-spatial relationships that exist in, between, and around these archives. Therefore, it's argued that digitisation provides new opportunities for cultural participation and therefore the development of collective identities which it is over simply a technical method of putting collections on-line. It reshapes the socio-spatial relationships of teams over time [19].

\subsection{Cultural Identities and School Values}

A positive sense of cultural possession is expounded to numerous positive individual developments, admire protection against feelings of confusion, fear, or threat caused by the expertise of discrimination. robust transmitted identities are related to a range of indicators of adjustment, as well as tutorial engagement, action, and prosocial behavior. abundant of the acculturation analysis supports that prime identification with each cultures is related to favorable psychological and college adjustment for young cultural minorities. In distinction, in a very recent study from Kurjenoja \& Hernández (2015), solely the thought identity of cultural minority youth was related to college action, whereas each heritage and thought identity were related to psychological adjustment, as well as higher life satisfaction and reduced drawback behavior [20]. Some authors argue that the college context in Yogyakarta could have terribly high absorptive pressures, wherever students are expected to adapt to thought culture whereas ignoring their heritage culture. Hence, in associate absorptive faculty context, accentuation thought identities could also be additional necessary to highschool success than hereditary identities. another rationalization is that a additional developed hereditary identity could also be indirectly coupled to attainment through psychological adjustment. we tend to increase this discourse and investigate the cultural associations of youth minorities between cultural identity, life satisfaction, and schools values in the context of school in Yogyakarta.

\subsection{The Influence of Teachers on the Transmission of Socio-cultural values}

The real change from conventional family-based education to formal school-based education from cultural materials underlines the value of teachers being familiar with local cultures and being able to pass on relevant knowledge on socio-cultural issues to students in ways that are acceptable to local communities [10], [10] [11], [18], [21]. When the majority of teachers who teach do not come from the region where they teach, they create values that are internalized not by the practices of the local culture, but by values of various cultures. The results of the interview indicated that It is difficult for a teacher to communicate the principles that remain in 
community practices unless the teacher has been interested in local culture for a long time. The variation in the sense of importance to a tradition in society is also very likely for teachers who have little background in education, so it seems confusing.

At identical time, lecturers are troubled to return to terms with their own roles within the method of training students as provisions for community life by counting on experiences and learning plans developed antecedently. In such circumstances, it's virtually bound that components of AN external culture are going to be introduced, and with their introduction, the loss of native ancient culture will occur. maybe, several of the songs, dances, and chants appointed by grade school youngsters as their favorites don't seem to be of native origin however from outside cultures. However, this development mustn't be attributed to any single cause.

\subsection{Implicit Attitude Transmission Micro Mechanisms}

The potential mechanism is that the observation of the behavior of others from cultural practices. Cultural practices embrace all culturally important types of behavior; Examples include standard nonverbal behaviors (e.g., greetings love shaking hands, bending over, touching the nose [22]) to distinctive forms of language use (e.g., use of adjectives vs. verbs [23]) and a lot of complicated sequences of supported coordinated actions by social establishments. significantly, some cultural practices imply favorable or unwelcome responses to things so individuals will acquire implicit attitudes by observant prevailing cultural practices that imply the attitudes of others [24]. These findings suggest that implicit attitudes can be transmitted by observing other people's cultural practices - nonverbal behaviors that are highly evaluative in this respect. this implies fascinating prospects concerning cultural transmission mechanisms for cultural practices and implicit attitudes a lot of loosely.

\subsection{Explicit Instructions}

Explicit teaching happens in most, if not all, human societies. Some teaching takes the shape of formal education in school or at work; others could also be a lot of informal, resembling delicate feedback regarding mistakes. Through formal and informal channels, newcomers to a culture acquire cultural practices and connected attitudes. Not solely is collective culture nice, however also structure culture is transmitted by a mix of express socialization ways yet as spontaneous learning by newcomers[24]. However, to our information, there seems to be no direct take a look at of the thought that the transmission of cultural practices and implicit attitudes happens with higher fidelity once newcomers are expressly educated to be told than once they are not [25], [26].
Regarding express instruction, associate degree analogy will be drawn with intentional (vs. incidental) learning, within which individuals are expressly educated (or not) to be told sequences of behavior [27]. Recent analysis has found that some sequences of behavior, which can be generally equated with cultural practices, are easier to be told on purpose than incidental conditions, however different sequences are higher studied beneath incidental than intentional conditions [11]. This implies that it's not continually the case that cultural practices are probably higher transmitted with express instruction than while not. Moreover, the analogy between intentional vs incidental learning and tutorial vs. non-instructional learning isn't good. once cultural practices are educated to newcomers, the newcomer's learning is most likely intentional, however once no express instruction takes place, it's not clear whether or not the training was intentional or incidental [20]. Newcomers could on purpose or accidentally try and learn implicit cultural practices or attitudes. Moreover, it's not clear however express instruction from cultural practices affects the transmission of implicit attitudes.

\subsection{Institutionalization}

The institutionalization of cultural practices may also increase the accuracy of cultural transmission. we propose that a minimum of 3 parts are essential for the institutionalization of cultural practices. Cultural observe is institutionalized in such how that it's seen as having properties love social facts as a result of (a) it is widespread (that is, the majority conjointly own it), (b) is embedded within the intersubjective understanding of individuals in the collective (not simply the understanding shared by people, however they conjointly suppose that their understanding is shared, and (c) has time continuity, in order that cultural practices are seen as being passed down from one generation to ensuing within the past, and doubtless thus within the future [11]. We propose that this property makes observe culture isn't simply what bound folks do, however what's done as a part of the "goal" of the method of life, or what it's, outside the here and currently.

When institutionalized during this method, cultural practices are usually not questioned, and alternatives are thought-about. albeit it's recognized, questioned, and critically in person assessed, it may be thought-about a default, routine, and standard method of doing that individual needs cannot amendment. Institutionalization will even generate motivation to amass and continue a observe in order that those who take the institutionalized cultural practice as a right can study it and pass it on as a matter in fact. That said, organizations may be understood, a minimum of partially, as associate degree institutionalized set of cultural practices.

Zucker (1977) provides proof for the argument that institutionalization enhances cultural transmission [28]. He replicated the experiments of Jacobs and Joseph 
Campbell (1961) beneath 3 completely different conditions. Beneath conditions of private influence, participants are given directions to create correct judgments in problem-solving teams. In conditions of the structure context, the instruction emphasizes the temporal continuity of the procedure setting autokinetic motion experiments, even supposing the those who participate within the procedure amendment (even replace the recent one) [29]. However, it's not famous whether or not identical impact happens for implicit attitudes.

\section{CONCLUSIONS}

Cultural practices are often transmitted through imitation. That is, those that are unaccustomed a cultural cluster (that is, newcomers) imitate the cultural practices of these who are within the cluster for a few time (i.e., those who are old); by doing therefore, newcomers learn to hold out the cultural practices of the previous folks. variety of theorists, past and gift, have argued that imitation is one in every of the central mechanisms of cultural transmission. within the absence of migration flows or alternative mutations, people retain their values, and youngsters acquire these values from family or peers. However, thanks to migration, the 2 cultural forces have opposite effects on people in migrator and autochthonous communities.

It is documented within the literature and analysis results that cultural transmission in heterogeneous populations consisting of people with success transmits their traits into their roles. this happens once oldsters are less curious about investment in family education as a result of there are a lot of and more families who have completely different characteristics. what is more, this happens as a result of once the family pedagogy fails, the upper the amount of migrant families, the upper the chance that a baby can acquire migrant characteristics through peer socialization. the academic atmosphere features a important role within the method of sending socio-cultural values to children.

\section{REFERENCES}

[1] K. Van Eijck, "Socialization, education, and lifestyle: How social mobility increases the cultural heterogeneity of status groups," Poetics, vol. 26, no. 5-6, pp. 309-328, 1999.

[2] W. An and B. Western, "Social capital in the creation of cultural capital: Family structure, neighborhood cohesion, and extracurricular participation," Soc. Sci. Res., vol. 81, no. August 2018, pp. 192-208, 2019.

[3] T. Verdier and Y. Zenou, "The role of social networks in cultural assimilation," J. Urban Econ., vol. 97, pp. 15-39, 2017.

[4] A. Whiten and E. van de Waal, "Social learning, culture and the 'socio-cultural brain' of human and non-human primates," Neurosci. Biobehav. Rev., vol. 82, pp. 58-75, 2017.

[5] M. Print, "Social and cultural capital in education," Int. Encycl. Educ., pp. 97-102, 2010.

[6] H. Haste and S. Abrahams, "Morality, culture and the dialogic self: Taking cultural pluralism seriously," Journal of Moral Education. 2008.

[7] D. Anzola, D. Rodríguez-cárdenas, and D. Rodríguez-cárdenas, "A Model of Cultural Transmission by Direct Instruction : An Exercise on Replication and Extension," Cogn. Syst. Res., 2018.

[8] J. G. O’Neill and D. H. R. Spennemann, "Education and cultural change: A view from Micronesia," Int. J. Educ. Dev., vol. 28, no. 2, pp. 206-217, 2008.

[9] E. Menardo, G. Balboni, and R. Cubelli, "Environmental factors and teenagers' personalities: The role of personal and familial Socio-Cultural Level," Behav. Brain Res., vol. 325, pp. 181-187, 2017.

[10] A. Litina, S. Moriconi, and S. Zanaj, "The Cultural Transmission of Environmental Values: A Comparative Approach," WORLD Dev., vol. xx, 2016.

[11] Y. Kashima, S. M. Laham, J. Dix, B. Levis, D. Wong, and M. Wheeler, "Social transmission of cultural practices and implicit attitudes," Organ. Behav. Hum. Decis. Process., vol. 129, pp. 113 $125,2015$.

[12] J. W. Creswell, Research Design: Qualitative, Quantitative, and Mixed Method Approaches, 4th ed. California: SAGE Publications, Inc., 2013.

[13] R. B. Johnson and L. Christensen, Educational research: Quantitative, qualitative, and mixed approaches. California: SAGE Publications, Inc., 2014.

[14] B. P. M. Creemers, L. Kyriakides, and P. Sammons, Methodological Advances in Educational Effectiveness Research. 2010.

[15] P. Leavy, Research Design: Quantitative, Qualitative, Mixed Methods, Arts-Based, and Community-Based Participatory Research Approaches. New York: The Guilford Press, 2017.

[16] P. Bourdieu, "The forms of capital," in Handbook of Theory and Research for the Sociology of Education, J. Richardson, Ed. New York: Greenwood Press, 1986, pp. 241-258.

[17] R. D. Putnam, Bowling Alone: The Collapse and Revival of American Community. New York: Simon und Schuster, 2000. 
[18] M. J. Lin, "The social and genetic inheritance of educational attainment: Genes, parental education, and educational expansion," Soc. Sci. Res., vol. 86, p. $102387,2020$.

[19] M. Tamariz, "Replication and emergence in cultural transmission," Phys. Life Rev., vol. 30, pp. 47-71, 2019.

[20] A. K. Kurjenoja and I. A. Hernández, "Cultural Processes, Social Change and New Horizons in Education," Procedia - Soc. Behav. Sci., vol. 174, no. 222, pp. 3405-3412, 2015.

[21] P. Thompson, "Learner-centred education and 'cultural translation,", Int. J. Educ. Dev., vol. 33, no. 1 , pp. 48-58, 2013.

[22] M. Kaya and G. Oran, "The Transmission of SocioCultural Codes in Teaching Turkish as a Foreign Language," Procedia - Soc. Behav. Sci., vol. 186, pp. 1208-1213, 2015.

[23] W. Wang and C. Vallotton, "Cultural transmission through infant signs: Objects and actions in U.S. and Taiwan," Infant Behav. Dev., vol. 44, pp. 98 109, 2016.
[24] S. Dumbrajs, "Intergenerational Cultural Transmission," Procedia - Soc. Behav. Sci., vol. 47, pp. 109-113, 2012.

[25] G. Csibra and G. Gergely, "Natural pedagogy as evolutionary adaptation," Philos. Trans. R. Soc. B Biol. Sci., vol. 366, no. 1567, pp. 1149-1157, Apr. 2011.

[26] R. Paradise and B. Rogoff, "Side by Side: Learning by Observing and Pitching In," Ethos, vol. 37, no. 1, pp. 102-138, Mar. 2009.

[27] K. Burger, "Intergenerational transmission of education in Europe: Do more comprehensive education systems reduce social gradients in student achievement?," Res. Soc. Stratif. Mobil., vol. 44, pp. 54-67, 2016.

[28] L. G. Zucker, "The Role of Institutionalization in Cultural Persistence," Am. Sociol. Rev., vol. 42, no. 5, p. 726, Oct. 1977.

[29] R. C. Jacobs and D. T. Campbell, "The perpetuation of an arbitrary tradition through several generations of a laboratory microculture.," J. Abnorm. Soc. Psychol., vol. 62, no. 3, pp. 649-658, May 1961. 